\title{
ESTABLISHMENT OF A DE JURE PEACE ON THE KOREAN PENINSULA: INTER-KOREAN PEACE TREATY-MAKING UNDER INTERNATIONAL LAW*
}

\author{
Eric Yong-Joong Lee**
}

\section{INTRODUCTION}

Written in 1795, ImManuEl KanT's essay “Toward Perpetual Peace: A Philosophical Sketch" begins with the pessimistic remark that humanity can find perpetual peace only in a vast grave where all the horrors of violence or those responsible for them would be buried. ${ }^{1}$ The great philosopher who introduced a modern definition of peace envisaged real peace as emerging from a state of nature among nations under a new form of cosmopolitan law based on a peaceful federation of all the peoples of the earth. ${ }^{2}$ Despite these and other ceaseless quests by thinkers and politicians since ancient times, ${ }^{3}$ achieving real peace in human society, especially in the international sphere, has not become tangible and has remained a vain ideal. Would it then really be impossible to obtain real peace even in our twenty-first century world society $?^{4}$

\footnotetext{
* This article is a fully revised version of Chapter VII of the author's dissertation, "Legal issues of inter-Korean economic cooperation under the armistice system" (Kluwer, 2002), for which the author was awarded the doctoral degree by the Faculty of Law, Erasmus University, Rotterdam, The Netherlands, on 7 June 2001. The author accepts full responsibility for the presentation of facts and views expressed in this article. Readers' comments will be cordially welcomed: <grotian@ yahoo.com>

"* As of 2003, Assistant Professor, Seoul National University, College of Law, Korea.

'See I.KANT, "Toward perpetual peace: a philosophical sketch", in H.REISS (ed.), Kant's Political Writings (Cambridge, 1970) 105.

${ }^{2}$ See J.Bohman \& M. L.BaChmann (eds.), Perpetual Peace: Essays on Kant's cosmopolitan ideal (The MIT Press, Cambridge, 1997) 1.

${ }^{3}$ On the ancient idea of peace, see G.ZAmPaglione, The Idea of Peace in Antiquity (Translated into English by R. Dunn, University of Notre Dame Press, 1973) 16 et seq.

${ }^{4}$ GaltuNG defines peace from two different perspectives: peace, in a negative sense, may be an absence of organized violence between major human groups like nations, while, in a positive sense, peace implies a pattern of cooperation and integration between major human groups. See J.GALTUNG,
} 
As the idea of peace became more popular in the twentieth century, people began to make serious efforts to establish a stable peace system that could be universally applied. ${ }^{5}$ This idealistic vision has finally been substantiated in the postwar international legal system by creating the new concept of collective security. A striking aspect of the collective security system is that the international society may set up an institution for the management of peace and security. This was realized by introducing a comprehensive ban on the use of force as a binding rule of law in Article 2(4) of the United Nations Charter. ${ }^{6}$ Although the system has not always worked in international crises, ${ }^{7}$ it has functioned as a norm and a means for the international society to limit conflicts and uphold an, albeit unstable, peace regime. Efforts to maintain peace and security have been made in many areas of the world, especially under the auspices of the UN; some have been successful, others less so. One of the regions where ultimate peace has not yet been achieved is on the Korean peninsula.

Arising from their division at the end of the Second World War and a resulting terrible civil war (1950-3), the conflict between North and South Korea became a chronic issue in the contemporary world. The Korean question did not remain a domestic problem between Koreans, but expanded as one of the several critical international issues in postwar international relations. The two Koreas, whose mutually hostile relations deteriorated even further during the Cold War, were unable to repair their relations in the first two decades after the end of the civil war. It was 1972 that a sudden change occurred in their extremely confrontational relationship. On 4 July in that year, the two Koreas issued a Joint Communiqué, a watershed in the search for peace on the Korean peninsula. The Joint Communiqué was followed by a resumption of discussions on the Korean question in the UN, then several meaningful exchanges and some instances of cooperation in the early 1970s. Despite its idealistic principles ${ }^{8}$ however, the Joint Communique failed to produce any further fruitful results. Inter-Korean relations had entered a second dark period by the end of the 1980s. At that time, there were few peaceful but, on the contrary, severe political activities and military confrontations along the Demilitarized Zone (DMZ).

With the end of the Cold War in the early 1990s, the two Koreas shifted their stance to a more friendly relationship and finally reached an historic

Peace: Research, Education, Action: Essays in Peace Research 1 (Christian Ejlers, Copenhagen, 1975) 29.

5 For details on peace studies, see G.A.LOPEZ, Peace Studies: past and future (Sage Publications, Newbury Park, 1989).

${ }^{6}$ Art.51 of the Charter, however, provides the right to collective and individual self-defence against an armed attack. See P. MALANCZUK, Akehurst's Modern Introduction to International Law, 7th edn. (Routledge, London, 1997) 27.

7 E.g. the 1956 Suez crisis, the 1961 Cuban missile crisis, the Vietnam War, etc.

8 See infra, text at n.21. 
Agreement on Reconciliation, Non-aggression and Exchanges and Cooperation (the Basic Agreement) in 1991. However, although it comprises a wide range of accords in the fields of political and military as well as of mutual economic cooperation, the Basic Agreement has failed both to bring about a peace regime and to lead to the conclusion of the desired peace treaty. The establishment of a stable peace regime has thus been left for the Korean people to achieve in the twenty-first century.

The primary purpose of this paper is to explore the possibility of establishing a peace system on the Korean peninsula and its conditions from an international legal perspective. History shows that peace, especially among nations, is more stable when it is set within a legal and institutional framework. Such de jure peace ${ }^{9}$ requires the successful installation of legal measures for the establishment and protection of the desired status quo. Accordingly, an important issue is that of finding a way to set up the legal framework. The most frequently adopted way is the conclusion of a peace treaty. This is also applicable to Korea. The current armistice agreement could be replaced by a peace treaty that may function as the legal foundation for a reliable peace regime on the Korean peninsula. An examination of the legal problems involved is, however, indispensable before the making of a peace treaty between North and South Korea can begin.

Our inquiry consists of four parts. In section 2 the origin and evolution of the Korean conflict will be reviewed and the quest for peace under the armistice system examined. For a better understanding of our topic Section 3 will approach the matter of peace treaty-making from an historical perspective. In an initial sub-section, some comparison will be made of peace treaties in Western Europe and in East Asia. As an example of recent state practice, a brief review will be offered of the process of German reunification. Section 4 will be devoted to the critical legal problems involved in the making of an inter-Korean peace treaty. Among the points of contention that stand in the way of concluding an inter-Korean peace treaty are the qualification of the parties in the process, the status of the United Nations Command (UNC) on the Korean peninsula, and the question of the United States armed forces stationed in South Korea. The relation of each factor to the making of a peace treaty will be analyzed from the international law perspective. In section 5 the legal methods and procedures of the making of a peace treaty will be examined. In a sub-section, the inter-Korean issue will be discussed in light of the procedures laid down in the Vienna Convention on the Law of Treaties of 1969. Finally, legal questions concerning the replacement of the armistice agreement with a peace treaty will be explored.

9 On the "de jure peace," see H.KelSEN, Peace Through Law (Chapel Hill, North Carolina, 1944) 3-9. See also E.LUARD, Conflict and Peace in the Modern International System (Little Brown and Co., Boston, 1968) 1-28. 


\section{THE QUEST FOR PEACE OF THE KOREAN PEOPLE}

\subsection{A brief review of the Korean conflict}

The origin of the contemporary Korean conflict can be traced back to the division of Korea into the north and the south in 1948. At that time the domestic and international environment was not favorable for the Korean people, who had just regained their independence after 35 years of Japanese occupation, to establish a single government. Instead, two separate governments following different ideologies were eventually set up, one in the north and the other in the south of the Korean peninsula. In the south, the Republic of Korea (ROK) was formally inaugurated on 15 August 1948 with Dr. SYNGMAN RHEE ${ }^{10}$ as its first president. ${ }^{11}$ In the north, which had undergone a socialist revolution under Soviet guidance, the regime led by KIM IL-SUNG organized the Chosun (Korean) Workers' Party and the People's Congress in April 1948. ${ }^{12}$

Less than two years after the establishment of the two governments, fullyfledged military hostilities broke out on the Korean peninsula as the North Korean People's Army crossed the Thirty-eighth parallel on 25 June $1950 .{ }^{13}$ The South Korean army, with four ill-equipped US divisions, had been rushed into battle and was overwhelmed by the North Korean forces. As time went by, however, the front line was stabilized along the Thirty-eighth parallel and in early 1951 the Korean War reached a stalemate. Through a suggestion for a cease-fire by the Soviet representative in the UN Security Council,

\footnotetext{
${ }^{10}$ For details on President Syngman RHEE, see R.Oliver, Syngman Rhee: The Man behind the Myth (New York, 1951); id., Syngman Rhee and American Involvement in Korea 1942-1960 (Panmun Books Co, Seoul, 1978). See also KIM QUEE-YOUNG, The Fall of Syngman Rhee (Institue of East Asian Studies, Berkeley, 1983).

$"$ The UN General Assembly recognized the ROK government as the sole legitimate government over that part of Korea [south of the $38^{\text {th }}$ parallel], where the UN Temporary Commission on Korea was able to observe the election. UNGA Res.195 (12 December 1948).

12 See Kim HaKjoON, Fifty years' history of North Korea (Dong-ah Publishers, Seoul, 1995) 124-30.

13 The English books and articles concerning the Korean War are as follows: R.LECKIE, Conflict: The history of the Korean War (New York, 1962); G.WINT, What Happened in Korea: A study in collective security (London, 1954); E. O'BALLANCE, Korea: 1950-1953 (London, 1963); D.Rees, Korea: the limited war (New York, 1964); C.BERGER, The Korean Knot: A military-political history (Philadelphia, 1964); H.J.MidDlETON, The Compact History of the Korean War (New York, 1965); L.S.KAPLAN, "The Korean war and U.S. foreign relations", in F.H.HELLER (ed.), The Korean War: A 25-year perspective (Lawrence, 1977); J.GOULDEN, Korea: the untold story of the war (New York, 1982); B.CummINGS (ed.), The Korean-American Relationship, 1943-53 (Seattle, 1983), etc. For a recent study on the origin and character of the Korean War, see CHOE JANG-JIP, Conditions and Prospects of Korean Democracy (in Korean, Namam Publishers, Seoul, 1996).
} 
negotiations finally began on 10 July 1951 at the city of Kaesong. ${ }^{14}$ Little compromise was reached before early $1953 .{ }^{15}$ One of the most critical issues was the exchange of the POWs. The deadlock in the talks was broken by two major international events: the victory of DWIGHT EISENHOWER in the US presidential election ${ }^{16}$ and the death of STALIN in March of 1953. As a result of these changes, the two Korean sides agreed on the critical POW problem. Finally, a ceasefire agreement was signed on 27 July $1953^{17}$ by the UN Commander-in-Chief ${ }^{18}$ and the Communist Representatives ${ }^{19}$ at Panmunjeom, a small town in the middle of the Korean peninsula. The resulting armistice system has now been in force for the past half-century.

\subsection{The beginning of peace on the Korean Peninsula}

In spite of the cease-fire, the parties continued to clash with each other at every stage of domestic and international politics during the Cold War period. Few initiatives towards an improvement of relations were taken, and by the end of the 1960s the two Koreas regarded each other simply as hostile and illegal insurgents.

In the early 1970s, however, a new development took place between the two sides; the two Koreas, after several secret meetings between high-level government officials, ${ }^{20}$ rather suddenly, on 4 July 1972, issued the Joint

\footnotetext{
14 At the opening meeting of the truce talks the delegations from North Korea and China proposed two items for discussion: (1) the determination of the $38^{\text {th }}$ parallel as the military demarcation line and for the establishment of a demilitarized zone, and (2) the withdrawal of all foreign armed forces from Korea. The items on the agenda of the United Nations Command delegation were: (1) agreement on a demilitarized zone across Korea, (2) the cessation of hostilities and acts of armed forces under conditions which would assure non-resumption of hostilities in Korea. See T.C.JoY, How Communists negotiate (Macmillan, New York, 1955) 19.

15 On the process of the truce talks in this period, see KIM HAKJOON, The Unification Policy of South and North Korea (S.N.U.Press, Seoul, Korea, 1977) 130-4.

${ }_{16}$ During the campaign, the Republican presidential candidate, D.EISENHOWER, pledged to bring the war to a conclusion. On the change of US policy on Korea at that time, see D.REES, Korea: the limited war (McMillan, London, 1964) 385-402. On the issue of the Korean War during the 1952 US presidential election campaign, see R.J.CARIDI, The Korean War and American Politics: The Republican Party as a case study (Univ.of Pennsylvania Press, 1968) 209-45.

17 "Agreement between the Commander-in-Chief, United Nations Command, on the one hand, and the Supreme Commander of the Korean People's Army and the Commander of the Chinese People's Volunteers, on the other hand, Concerning a Military Armistice in Korea", UN Doc.S/3079 (7 Aug. 1953). For the original text of the Armistice Agreement, see Documents on International Affairs 1953 (Royal Institute of International Affairs, Clarendon Press, Oxford, 1954) 386-405.

${ }^{18}$ General of the US Army MARK CLARK.

19 KIM IL-SUNG, Commander-in-Chief of the North Korean People's Army and PENG DeHUAI, Commander of the Chinese People's Volunteers' Army.
}

20 See Korea Herald of 4 July 1972. 
Communiqué mentioned above and containing "seven principles for peace and reunification of the divided fatherland". ${ }^{21}$

Against the background of these developments the Korean question was again placed on the agenda of the United Nations and the First Committee of the UN General Assembly in 1973 began renewed discussions on the matter. ${ }^{22}$ The debates continued in the next two sessions in 1974 and 1975. However, the process was halted by a border incident that occurred on 18 August 1976, in which two US soldiers were killed by North Korean soldiers. ${ }^{23}$ Due to this incident, the supporters of the two sides in the United Nations withdrew their respective proposals on the subject. ${ }^{24}$ The topic would not again be discussed in the UN General Assembly until the two Koreas simultaneously became UN members on 17 September $1991 .^{25}$

In spite of the idealistic sounding Communiqué of 1972 and the earnest efforts of the international community, the two Koreas could not overcome their deep-rooted and long-standing mutual mistrust, and neither reunification nor a more friendly relationship was attained. There were no further developments; the political and military standoff continued in the following decade.

\subsection{New peace in the 1990s: The Basic Agreement}

A new wave of reconciliation between the two Koreas came with the end of the Cold War. Several important events affected the Korean peninsula. Among them, the dissolution of the former Soviet Union and the reunification of East and West Germany were the most conspicuous events not only in an international political but also an emotional sense. Following these environ-

${ }^{21}$ In the seven principles the two sides agreed on the following: (1) make independent efforts to achieve the reunification through peaceful means; (2) neither defame nor slander one another; (3) carry out various exchanges in many areas; (4) cooperate positively to seek an early success of the Red Cross Conference; (5) install and operate a direct telephone line between Seoul and Pyongyang; (6) create and operate a Coordinating Committee; and (7) convince that these agreements correspond with the common aspiration of the entire people eager to see early unification of the fatherland. For details, see KIM MYUNG-KI, South-North Joint Communique and International Law (in Korean, Beobmunsa Publishers, Seoul, 1975).

${ }_{22}$ The first discussion on the Korean question in the UN was initiated by the United States in the General Assembly on 17 Sept.1947. See E.J.OSMANCZYK (ed.), The Encyclopedia of the United Nations and International Agreements (Taylor and Francis, London, 1985) 442.

${ }^{23}$ For details, see Korea Times of 19 Aug.1976.

${ }^{24}$ See KoH KWANG-LIM, "The Korean unification question and the United Nations", in: T.BUERGENTHAL (ed.), Contemporary Issues in International Law: Essays in honor of Louis B. Sohn (N.P.Engel Publisher, Strasbourg, 1984) 548.

25 UNGA Res.46/1 (17 September 1991). 
mental changes ${ }^{26}$ the two Koreas joined the United Nations in 1991. North and South Korea resumed high-level talks and finally, on 13 December 1991, concluded the Agreement on Reconciliation, Non-aggression and Exchanges and Cooperation between North and South Korea (The Basic Agreement). ${ }^{27}$ This Agreement contained progressive legal measures for the shaping of new inter-Korean relations in the post-Cold War era.

Reflecting a spirit of inter-Korean reconciliation and cooperation, this historic Basic Agreement is divided into four main chapters containing a total of 25 Articles. ${ }^{28}$ Chapter I, on South-North Reconciliation, states critical provisions relating to the establishment of new inter-Korean relations. In Article 1, the two Koreas agreed not only to accept the legitimacy of each other's political entity, but also to guarantee the continuity of their separate systems. ${ }^{29}$ In Article 5, they promised "to transform the present state of armistice into a solid state of peace." This provision represents a great step forward towards establishing a durable de jure peace regime on the Korean peninsula. ${ }^{30}$ In Chapter II, on South-North Non-Aggression, it was agreed not to use military force against each other,${ }^{31}$ but to resolve differences and disputes that might arise between them through "dialogue and negotiation". ${ }^{32}$ The provisions of Chapter III, South-North Exchanges and Cooperation, have had a long-term and significant impact on promoting inter-Korean cooperation. This is especially so in Article 15 where the two Koreas agreed "to promote an integrated and balanced development of national economy and the welfare of the entire people." Chapter IV, finally, dealt with Amendments and Effectuation and laid down certain administrative matters.

The adoption of the Basic Agreement was not only an unprecedented step, but also a cornerstone of the postwar inter-Korean relationship. As an interim stage between the armistice and a stable peace regime, the Basic Agreement may help the two Koreas start an era of real peace and cooperation.

\footnotetext{
26 In addition to these changes, the death of the North Korean president, KIM IL-SUNG, in 1994, and several floods combined to make the new North Korean regime under KIM JONG-IL look for a way to open its doors to the outside world in order to overcome the crisis. On the political situation of the post-KIM IL-SUNG era of North Korea, see T. HENRIKSEN \& J. Mo (eds.), North Korea after Kim Il Sung: continuity or change (Hoover Institution Press, Stanford, 1997).

27 English translation in 2 AsYIL (1992) 409 et esq.

${ }^{28}$ For a commentary on the Basic Agreement, see KIM MYUNG-KI, The Treaties on Basic Agreement between The South and The North (in Korean) (The Institute of International Affairs, Seoul, 1992).

29 "The South and the North shall recognize and respect each other's political systems."

30 See KWAK TAE-HWAN, "Inter-Korean military confidence building: a creative implementation formula", 24 Korea Observer (1993) 379-80.

31 Art. 9 Basic Agreement.

32 Art. 10 Basic Agreement.
} 


\section{DEVELOPMENT OF PEACE TREATY-MAKING UNDER CUSTOMARY INTERNATIONAL LAW}

\subsection{A comparison of peace treaties in Western Europe and East Asia}

\subsubsection{The West}

The usual method of terminating armed conflicts and restoring normal peaceful relations between former belligerent states is to conclude a peace treaty. ${ }^{33}$ Western practice pertaining to peace treaty-making dates back to Greek and Roman times. ${ }^{34}$ Ancient Greece was familiar with the prototype of a peace treaty. City-states developed an advanced system of balance of power and regularly provided a joint commitment to sanctions against the perpetrator of a breach of the peace. ${ }^{35}$ This Greek experience influenced thinking in the Roman period. ${ }^{36}$ Under Roman law, ${ }^{37}$ a series of peace treaties was concluded..$^{38}$ In contrast to the Roman period, peace among European states was rare in the Middle Ages, often falling prey to conflicting political interests of feudal lords and the authority of the Catholic Church. ${ }^{39}$

From the 17th century on, peace finally began to be recognized as a wellestablished institution among European nations. Among contemporary thinkers, ${ }^{40}$ the famous Dutch jurist, Hugo Grotius (Hugo de Groot) ${ }^{41}$

33 See J.STONE, Legal Controls of International Conflict, 2nd edn. (Maitland Publications, Sydney, 1959) 640 .

${ }^{34}$ The first known peace treaty in the history of mankind was concluded between the Egyptian Pharaoh, Rameses II, and the King of the Hittites, Hattusilis II. See S.VEROSTA, "Peace Treaties", in R.BERNHARDT (ed.), Encyclopedia of Public International Law (henceforth: EPIL) instalment 4 (1982) 102.

35 On the penal system of ancient Greece, see A.R.W.HARRISON, The Law of Athens (Oxford, 1971) 168-85.

${ }^{36}$ Much of Roman law was copied from Greek philosophical writings. See A.STEPHENSON, A History of Roman Law (Little Brown and Co., Boston, 1912) 7. See also W. KUNKEL, An Introduction to Roman Legal and Constitutional History (English transl., Oxford, 1973) 24.

37 On Roman Law and its distinction between jus civile and jus gentium, see J.A.C.THOMAS, Textbook of Roman Law (North-Holland Publishing Co., Amsterdam, 1976) 63-4.

${ }^{38}$ E.g., a treaty concluded between Rome and Carthage in the first year of the Republic (509 B.C.). See H.F.JolowICZ, Historical Introduction to the Study of Roman Law (Cambridge, 1939) 100. ${ }^{39}$ See Verosta, loc.cit.n.34 at 103.

${ }^{40}$ Among those who made great contributions: FRANCISCO VITORIA, FRANCISCO SUAREZ, ALBERICO GENTILI and HUGO GROTIUS. On the theories of jurists of the $17^{\text {th }}$ century, see J.M.KeLLY, A Short History of Western Legal Theory (Oxford, 1992) 211-9, or A.NuSSBAUM, A Concise History of the Law of Nations (Macmillan, New York, 1954) 79-114. On the Spanish origin of the law of nations, see J.B.SCOTT, Francisco de Vitoria and His Law of Nations (Oxford, 1934).

${ }^{41}$ On the life and works of Hugo Grotius, see H.Vreeland, Hugo Grotius (Oxford, 1917); W.S.M.KNIGHT, The Life and Works of Hugo Grotius (Sweet \& Maxwell, London, 1925); E.DUMBAULD, The Life and Legal Writings of Hugo Grotius (Univ.of Oklahoma Press, 1969); and C.S.EDWARDS, Hugo Grotius: The miracle of Holland (Nelson-Hall, Chicago, 1981). 
elaborated on the legal concepts of war and peace in his masterpiece, De Jure Belli Ac Pacis (On the Law of War and Peace).$^{42}$ A kind of collective security pact was concluded among the European countries by way of the Westphalia Peace Treaty of $1648 .^{43}$ The implied system of maintenance of peace was later followed by the Vienna Congress of $1815^{44}$ and was further developed by the Conventions drawn up by the two Hague "Peace Conferences" of 1899 and 1907, and the subsequent Treaty of Versailles of $1919.4^{45}$ These treaties $^{46}$ provided the institutional bases for a peace system throughout Europe.

\subsubsection{East Asia}

East Asian thinking on peace and peace treaties is considered to have started more than two thousand years ago, with the first meaningful institution for peace established in ancient China. During the Spring and Autumn Period (722-481 B.C.), dozens of small states existed with one another as a league of states in China proper. One of the principal functions of the league was the peaceful settlement of disputes between member states, ${ }^{47}$ which developed rules and customs ${ }^{48}$ for peace enforcement. This might be considered as the prototype of a peace system in East Asia. ${ }^{49}$

42 For the original text, see W.WHEWELL, Hugonis Grotii De Jure Belli et Pacis (accompanied by an abridged translation) I-III (Cambridge, 1853). On the interpretation of the text, see C.VAN VOLLENHOVEn, The Framework of Grotius' book De Jure Belli Ac Pacis (1625) (Amsterdam, 1932).

${ }^{43}$ Signed on 24 Oct.1648 ending the Thirty Years' War (1618-48), the Westphalia peace treaty was a major landmark in the history of the law of nations. It was the first European charter in a modern sense that established peace on the basis of balance of power, introducing the era of a community of sovereign and independent states of equal status. See A.M.ZAYAS, "Peace of Westphalia 1648", EPIL inst.7 at 536.

44 Terminating the Napoleonic Wars, a European Congress held in Vienna in 1815 concluded the Final Act of the Vienna Congress on 9 June 1815. This Final Act consisted of a principal document and 17 annexes. See F.MÜNCH, "Vienna Congress (1815)", EPIL inst.7 at 523.

45 The Treaty of Versailles, concluded at the Paris Peace Conference of 1919, was the keystone of the League of Nations. See G.EGERTON, The League of Nations: an outline history 1920-1946 (The UN Library, Geneva, 1996), 24.

46 Some major peace treaties concluded in Europe between the 1648 Westphalia Treaty and the 1919 Paris treaties were the Peace Treaties of Utrecht (1713), Aix-la-Chapelle (1748), and Paris (Crimean War, 1856).

${ }^{47}$ Mediation and arbitration were popular methods for settling disputes at that time. See WANG TIEYA, "International Law in China: historical and contemporary perspectives", 221 Hague Recueil (1990-II), (Martinus Nijhoff Publishers, The Hague) 219-25.

${ }^{48}$ For example, it was regarded as a grave breach of interstate norms for a league member to use force in settling a dispute without first having obtained the permission of the league leader. See J.A.Cohen \& ChIU Hungdah, People's China and International Law, Vol.2 (Princeton, 1974), 1113.

49 Opinions differ as to whether this can be regarded as international law in a modern sense. NUSSBAUM has denied that historical events and practices in ancient China have revealed anything 
Since $C h$ 'in's unification in 221 B.C. China, being the central and imperial state of Asia, developed a new international order regulating the relations with its neighboring countries on the basis of the customary, so-called "tribute", system. ${ }^{50}$ It functioned by maintaining a power balance in East Asia under imperial China and sometimes manifested itself in concrete treaties. ${ }^{51}$ As early as the mid-1 $17^{\text {th }}$ century the European law of nations was introduced into East Asia. ${ }^{52}$ The first incident where $C h$ 'ing accepted the Western law of nations as a universal legal system was the conclusion of the Treaty of Nechinsk with Russia in 1689. Beginning with the Opium War in 1839, with Western firepower, however, brought China a certain practical familiarity with "unequal" treaties. The first unequal treaty imposed upon China was the Treaty of Nanjing signed on 29 August $1842,{ }^{53}$ supplemented by the Treaty of Humen-chai the following year. The 1844 Treaty of Wanghsia between China and the United States and the 1844 Treaty of Whampou between China and France contained similar provisions, replacing the old Canton trade system by a new one based on the modern law of nations. ${ }^{54}$ A series of treaties eventually started a new era of Western intrusion and unequal treaties in Chinese history ${ }^{55}$ they were in place for more than a century, until the People's Republic of China (PRC) abrogated them in $1949 .{ }^{56}$

that could, even in a broad sense of the word, be considered as international law, whereas KOROVIN claimed that it is China, India, Egypt and other ancient Asian states which should be considered the birthplace of international law. See NUSSBAUM, op.cit.n.40 at 10, and E.A.KOROVIN, International law (The Institute of State and Law of the Academy of Science of the USSR, Moscow, 1960), 27. so The tribute system linked foreign trade and other aspects of the relations between the Chinese empire and other nations in East Asia to China's culturo-centric world-view of China being not only the largest and oldest among the states of the world, but also the source of their civilization. See Cambridge History of China (1986) 201. See also WANG TIEYA, loc.cit.n.47 at 219-25.

51 The customary law of treaties was highly developed in East Asia in the province of mutual defense and what would nowadays be called diplomatic and consular relations. Historical records show that the first Sino-Korean peace treaty was concluded between the Han dynasty of China and the Kochosun dynasty of Korea in 108 B.C.for the termination of a war between them. See LEE KI-BAIK, A New History of Korea (Ilchogak Publishers, Seoul, 1984) 38-40.

52 See J.E.WILLS, "Ch'ing's relations with the Dutch, 1662-1690", in J.K.FAIRBANK (ed.), The Chinese World Order: traditional China's foreign relations (Cambridge, 1968) 248.

53 The main provisions of the Treaty of Nanjing dealt with the opening of five ports to British trade and residence, the cession of Hong Kong to Great Britain, and payment of indemnity.

54 The most-favored-nation status was accorded to the signatory states in those treaties.

55 The number of all treaties, agreements, regulations, etc., from 1842 to 1949 is 1175 , of which four-fifths are made between China and foreign corporations and enterprises. They formed an important part of the unequal treaty regime in China. See WANG TIEYA (ed), The Comprehensive Collection of Old Treaties, Agreements, Regulations, etc., between China and Foreign Countries, 1689-1949 (in Chinese, Beijing, 1952-1962).

56 Art.55 of the Common Program of the Chinese People's Political Consultative Conference of 29 September 1949. 
As China had done, Korea and Japan opened their doors to the West by way of the new style of treaties. ${ }^{57}$ Japan abandoned its isolationist policy by concluding the US-Japan Treaty of Friendship of $1854 .{ }^{58}$ By this treaty, concluded in conformity with modern international law, Japan agreed to open the ports of Shimoda and Hakodate to provide the fuel, food and drinking water necessary for navigation, and to rescue ships and castaways. Similar treaties were concluded with Britain in 1854, Russia in 1855, and the Netherlands in 1856. Korea, meanwhile, opened its doors to the outside world throughthe 1872 Treaty of Kangwha and the 1882 US-Korea Treaty of Friendship and Commerce. ${ }^{59}$

\subsection{The German peace treaty-making: a case of recent state practice}

Following the surrender of the German armed forces on 7 and 8 May $1945,{ }^{60}$ the Allied Powers issued the Berlin Statement of 5 June 1945, whereby they assumed control as "the Supreme Authority in Germany." Berlin Statement was followed by the Paris peace treaties of 10 February 1947 between the "Allied and Associated Powers" on the one hand, and the various "former Axis Powers" except Japan and Germany on the other hand. ${ }^{62}$ A comprehensive settlement of the German question was made complicated by the division of Germany into four zones of occupation. After the failure to reach a solution between the Western and Soviet blocs, two separate governments were eventually established in the former German territory: the Federal Republic of Germany (FRG) in the west and the German Democratic Republic (GDR) in the east. It was not until the early 1970s that the two Germanys began to search for a way of overcoming their conflicts and reshaping their relations. Under the strong impetus of WILLY BRANDT's Ostpolitik, ${ }^{63}$ they finally concluded a series of treaties and set up a peace

\footnotetext{
${ }^{57}$ For details on the actual situation of these three countries at that time, see G.H.CURZON, Problems of the Far East (Longman, London, 1894).

58 See FujIO ITO, “One hundred years of international law studies in Japan”, 13 JAIL (1969) 19.

59 On Korea's opening of its doors by a series of modern style treaties, see CHAI NAM-YEARL, "Korea's reception and development of international law", in PAE JAE SCHICK et al., Korean International Law (Center for Korean Studies, Berkeley, 1981) 7-36. See also CHOI CHONG-KO, The Reception of Western Law in Korea (in Korean, Bakyoungsa Publishers, Seoul, 1982).

${ }^{60}$ See Act of Military Surrender of the German Armed Forces, in Official Journal of the Control Council in Germany, Supplement 1 at 6.

${ }^{61}$ See D.BLUMENWITZ, What is Germany?: Exploring Germany's status after World War II (Kulturstiftung, 1989) 30.

62 On the contents of the 1947 Peace Treaty, see E.VON PUTTKAMER, "Peace treaties of 1947", EPIL inst.4 at 117-22.

${ }^{63}$ On Ostpolitik, see R.TILFORD (ed.) The Ostpolitik and Political Change in Germany (Saxon House, Lexington, 1975); and L.L.WHETTEN, Germany's Ostpolitik: Relations between the Federal Republic and the Warsaw Pact countries (The Royal Institute of International Affairs, London, 1971).
} 
system in German territory. Having opened their doors to each other through the Traffic Treaty of 26 May $1972,{ }^{64}$ the two States then concluded the historical Treaty Concerning the Basis of the Relationship between the FRG and the GDR (the Basic Treaty) on 21 December 1972. The Basic Treaty contained groundbreaking regulations on East and West German State sovereignty, mutual inter-German recognition, representation of Germans, etc. ${ }^{65}$ The Basic Treaty was supplemented by implementing protocols concerning the exchange of permanent representatives ${ }^{66}$ the demarcation of a common border ${ }^{67}$ and the mutual understanding of their cultures and societies. ${ }^{68}$

Immediately after the Basic Treaty of 1972 came into effect, East and West Germany joined the United Nations simultaneously on 18 September $1973 .{ }^{69}$ This helped accelerate the normalization of inter-German relations. In the Prague Treaty of 11 December 1973 on reciprocal relations the two Germanys reached an agreement on the long-standing question relating to their borders. ${ }^{70}$ Through these efforts, the FRG finally reached a mutual understanding with the Soviet Union on the German question. The final outcome was the Conclusionary Act adopted on 1 August 1975 at the Conference on Security and Cooperation in Europe (CSCE) held in Helsinki. ${ }^{71}$ The CSCE Conclusionary Act, which was the result of the FRG's Ostpolitik ${ }^{72}$ and the Soviet Union's West Policy at that time, became an international footing for the German unification. ${ }^{73}$

In 1990 the legal process of German unification suddenly accelerated. On 2 July 1990 the FRG and GDR ratified the Treaty of 18 May 1990

\footnotetext{
${ }^{64}$ Just before making the Traffic Treaty, the two Germanys passed the Agreement between the Government of the FRG and the GDR on the Transit Traffic of Civilian Persons and Goods between the GRG and West Berlin (Transit Agreement) on 17 Dec.1971. The Transit Agreement, however, was only a governmental agreement implementing the Four Powers Agreement over Berlin of 3 Sept.1971. For details, see DOEKER and BRUECKNER, The Federal Republic of Germany and the German Democratic Republic in International Relations Vol.1 (1979) 377.

${ }_{65}$ Articles 1-4, 6 and 8 of the Basic Treaty of 1972. For details, see E.PLOCK, The Basic Treaty and the Evolution of East-West German Relations (Westview Special Studies in International Relations, Westview, Boulder, 1986) 11.

${ }^{66}$ Art. 8 of the Basic Treaty.

${ }^{67}$ Supplementary Protocol to Article 3 of the Basic Treaty.

${ }^{68}$ See BLUMENWITZ, op.cit.n.61 at 49.

69 UN Doc. A/9069 and S/10945.

70 According to the Prague Treaty, the nullification of the Munich Agreement of 29 Sept.1938 presents no territorial problems for the FRG, since it accepts that Germany only continued to exist after World War II within her 1937 borders. On the question of the German borders of 1937, see BLUMENWITZ, op.cit.n.61 at 24-8.

71 On the process of the CSCE, see A.PITTMAN, From Ostpolitik to Reunification: West GermanSoviet political relations since 1974 (Cambridge, 1992) 134-49.

72 See supra n.63.

73 See the BAHR Paper, published by the Press and Information Department of the government of FRG (cited from PITTMAN's book).
} 
Establishing a Monetary, Economic, and Social Union (The Treaty of German Union).

Table 3-A: Process of Peace Treaty-Making on the German Question.

\begin{tabular}{|c|c|c|c|}
\hline Treaty & Contents & Parties & Date \\
\hline $\begin{array}{l}\text { The } 1947 \text { Peace } \\
\text { Treaty of Paris }\end{array}$ & $\begin{array}{l}\text { The former Allies intended to settle } \\
\text { the postwar German question. }\end{array}$ & $\begin{array}{l}\text { Allied Powers } \\
\text { \& Axis Powers } \\
\text { except Japan }\end{array}$ & Feb. 101947 \\
\hline Traffic Treaty & $\begin{array}{l}\text { The first mutually binding treaty to } \\
\text { open the door to the other side } \\
\text { ending the hostile confrontation. }\end{array}$ & FRG \& GDR & May 261972 \\
\hline $\begin{array}{l}\text { The } 1972 \text { Basic } \\
\text { Treaty }\end{array}$ & $\begin{array}{l}\text { Legal grounds for new inter-Ger- } \\
\text { man relations: East-West German } \\
\text { State sovereignty, mutual recog- } \\
\text { nition, representation of Germans, } \\
\text { etc. }\end{array}$ & FRG \& GDR & Dec. 211972 \\
\hline $\begin{array}{l}\text { The Prague } \\
\text { Treaty }\end{array}$ & $\begin{array}{l}\text { Settlement on the long-standing } \\
\text { border question. }\end{array}$ & FRG \& GDR & Dec. 111973 \\
\hline $\begin{array}{l}\text { Conclusion-ary } \\
\text { Act of CSCE }\end{array}$ & $\begin{array}{l}\text { Mutual understandings between } \\
\text { FRG and USSR on the German } \\
\text { question. }\end{array}$ & FRG \& USSR & Aug. 11975 \\
\hline $\begin{array}{l}\text { The Treaty of } \\
\text { German Union }\end{array}$ & $\begin{array}{l}\text { Legal principles for establishing } \\
\text { monetary, economic and social } \\
\text { union as well as finance and } \\
\text { budget. }\end{array}$ & FRG \& GDR & July 21990 \\
\hline $\begin{array}{l}\text { The Unification } \\
\text { Treaty }\end{array}$ & $\begin{array}{l}\text { Agreements with respect to building } \\
\text { German unity. followed by the } \\
\text { Final Settlement }\end{array}$ & FRG \& GDR & Aug. 311990 \\
\hline
\end{tabular}

Source: A.D. Handcock \& H.A. Welsh (eds.), German Unification: Process and Outcomes, Westview, Boulder, 1994.

Consisting of six chapters and 38 articles ${ }^{74}$ the Treaty laid down the basic legal principles for the establishment of monetary, ${ }^{75}$ economic $^{76}$ and

\footnotetext{
74 The Treaty of German Union consists of the following chapters: Basic Principles (Chapter I); Provisions concerning Monetary Union (Chapter II); Provisions concerning Economic Union (Chapter III); Provisions concerning Social Union (Chapter IV); Provisions concerning Budget and Finance (Chapter V); Final Provisions (Chapter VI).

${ }^{75}$ On the principles of monetary union, see Art 10, para. 5 of the German Union Treaty.
} 
social $^{77}$ union as well as those for the element of the budget and finances ${ }^{78}$ of a unified Germany. ${ }^{79}$ Less than two months later, on 31 August 1990, the FRG and the GDR finally signed the epoch-making Treaty on the Establishment of German Unity (The Unification Treaty) ${ }^{80}$ in Berlin. The Treaty on the Final Settlement with respect to Germany followed on 12 September of the same year. ${ }^{81}$ (See Table 3-A)

The two Germanys thus succeeded in overcoming mutual confrontation and ultimately obtained political unification through a long and hard process. Although the treaties concerning the post-war German question might not have been formulated in the typical form of peace treaties from the viewpoint of the traditional law of war, ${ }^{82}$ they are nevertheless a good model for a modern-style pact of peace and as such may serve to assist in the peaceful resolution of international conflicts and restoration of friendly relations. The process that led to German reunification should be a valuable example for the two Koreas. First, the FRG and the GDR approached the issue from a domestic, German, perspective. They did not try to find solutions from outside, but to find an answer to the existing questions between themselves. Such a direct approach may have rendered those questions clearer to them. Second, they succeeded in creating a favorable international environment for peaceful unification, particularly through the CSCE Conclusionary Act with the Soviet Union, one of the most interested parties. Third, the two Germanys integrated the treaties relating to the unification process into their domestic legal systems.

\footnotetext{
76 Arts.11-16 of the Treaty of German Union.

77 Arts.17-25 of the Treaty of German Union.

78 Arts.26-32 of the Treaty of German Union.

79 On ratification of the treaty, the two Germanys on 14-16 July of the same year agreed on an eight-point unification plan.

${ }^{80}$ The Unification Treaty consists of the following chapters: Effect of Accession (Chapter I); Basic Law (Chapter II); Harmonization of Law (Chapter III); International Treaties and Agreements (Chapter IV); Public Administration and the Administration of Justice (Chapter V); Public Assets and Debts (Chapter VI); Labor, Social Welfare, Family, Women, Public Health and Environmental Protection (Chapter VII); Culture, Education and Science, Sport (Chapter VIII); Transitional and Final Provisions (Chapter IX).

${ }^{81}$ On the next day, the FRG concluded the Treaty on Good Neighborliness, Partnership and Cooperation with the Soviet Union in Moscow.

${ }^{82}$ From the viewpoint of the traditional law of war, the chief effect of a peace treaty is only the restoration of a condition of peace between former belligerents. See H.LAUTERPACHT (ed.), Oppenheim's International Law, Vol.2, 5th edn. (Longmans, London, 1935) 479.
} 


\section{LEGAL PROBLEMS PRECEDING THE CONCLUSION OF A PEACE TREATY BETWEEN THE TWO KOREAS}

\subsection{The legal nature of the current relationship between the two Koreas}

A preliminary problem to be dealt with in the matter of peace treaty making between North and South Korea is to define the current legal status of inter-Korean relations. Although no full-blown military clash has taken place since the end of the Korean War in 1953, and although the danger of open war on the Korean peninsula has definitely decreased, inter-Korean relations are still governed by the Armistice Agreement. Are the two Koreas at peace or are they not?

Under the traditional theory of the law of $w a r,{ }^{83}$ an armistice is as a temporary suspension of armed hostilities ${ }^{84}$ which are to be resumed on the expiration of the armistice period. ${ }^{85}$ An armistice should thus be distinguished from peace in the following sense: peace is based on the idea of normalization of relations between the former belligerents, whereas an armistice denotes only the factual cessation of war. In other words, armistice has only a negative connotation (negation of war), while peace has a positive meaning (including the conduct of diplomatic, economic and other relations). ${ }^{86}$ In modern state practice, however, a general armistice ${ }^{87}$ is regarded not merely as a temporary halting of hostilities, but as a kind of

\footnotetext{
${ }^{83}$ On the traditional theory of the law of war, see L.C.GREEN, The Contemporary Law of Armed Conflict (Manchester, 1993) Chaps.1 and 2; I.D. DE LuPIS, The Law of War (Cambridge, 1987); R.MILLER (ed.), The Law of War (Lexington, 1975); I.BROWNLIE, International Law and the Use of Force by States (Oxford, 1963) Part I; J.STONE, op.cit.n.33; A.D.MCNAIR, Legal Effects of War (Cambridge, 1948); T.BATY and J.H.MORGAN, War: its conduct and legal result (New York, 1915); and P.BORDWELL, The Law of War between Belligerents (Chicago, 1908).

${ }^{84}$ The traditional rules of armistice were firstly enshrined in Arts. 36 to 40 of the Hague Regulations respecting the Laws and Customs of War on Land (Hague Regulations, Annexed to Conventions II of 1899 and IV of 1907). An armistice is defined in the Hague Regulations as "a suspension of military operations by mutual agreement between the belligerent parties." Each party to an armistice agreement undertakes to notify all its competent authorities and armed forces of the suspension of hostilities. See S.VEROSTA, "Neutralization", EPIL inst.4 at 32. On the UN practice on armistice, see S.D.BAILEY, "Cease-fires, truce and armistice in the practice of the United Nations Security Council”, 71 AJIL (1977) 463-7.

85 Art.36 of the Hague Regulations.

${ }^{86}$ See J.MÖSSNER, "Non-aggression pact”, EPIL inst.4 at 33.

${ }^{87}$ Under Art. 37 of the Hague Regulations, an armistice may be general or local in character. The former means the suspension of hostilities pertaining to all military operations anywhere, while the latter refers to the suspension within a prescribed area only.
} 
de facto termination of $w_{a r}{ }^{88}$ to be completed later by a final peace treaty. ${ }^{89}$ Professor JULIUS STONE calls the Korean armistice a typical case of a modern-style armistice. ${ }^{90}$ The two opposing sides strongly desired to terminate their armed conflict through the armistice, ${ }^{91}$ and they have indeed not resumed armed hostilities since then. Seen from the perspective of the aforementioned modern armistice practice, ${ }^{92}$ the Korean armistice may indeed be regarded as a general armistice resulting in the two Koreas supposedly being at peace with each other. ${ }^{93}$ In view of the actual situation, however, one can hardly take peace between them for granted in the absence of a real legal and institutional foundation. That is why the current inter-Korean relations should be classified as an interim stage between de jure armistice and de facto peace.

\subsection{Qualification of the parties in the Inter-Korean peace treaty- making process}

The second question relating to the inter-Korean peace treaty-making process concerns the recognition of the direct parties concerned. The origin of this issue, raised mainly by North Korea, dates back to the negotiation period of the Armistice Agreement. North Korea's arguments concerning the question may be summarized as follows: ${ }^{94}$

\footnotetext{
${ }_{88}$ The modern practice of armistice commenced with a number of armistices concluded during World War I. For the relevant texts, see 13 AJIL (1919) Supp. at 80-96. A typical theory on this period has been presented by L.OPPENHEIM. See H.LAUTERPACHT, Oppenheim's International Law, Vol.2, 7th edn. (Longmans, London, 1952) at 596-9. The new concept of a general armistice was further developed through the series of general armistice agreements signed in 1949 between Israel on the one side and Egypt, Lebanon, Jordan and Syria on the other (see 42 UNTS 251-351), and reached its zenith in the Korean Armistice Agreement of 1953. On the historical evolution of the legal concept of armistice, see VEROSTA, loc.cit.n.84 at 32-3.

${ }^{89}$ See STONE, op.cit.n.33 at 643-4.

90 Id. at 644. The same argument may be found in J.G. STARKE's An Introduction to International Law (Butterworths, London, 1984) 546.

91 The ardent hope of the two sides to terminate the armed conflict is apparent in the preamble of the Armistice Agreement, as follows: “.... in the interest of stopping the Korean conflict, and with the objective of establishing an armistice which will ensure a complete cessation of hostilities and of all acts of armed force in Korea until a final peace settlement is achieved."

92 For details on the modern practice of armistice, see H.S.LEVIE, "The nature and scope of the armistice agreement", 50 AJIL (1956) 880-8.

${ }^{93}$ On the duration of the armistice, Art.V para. 62 of the Korean Armistice Agreement provides that, "The Articles and Paragraphs of this Armistice Agreement shall remain in effect until expressly superseded either by mutually acceptable amendments and additions or by provision in an appropriate agreement."

94 Unification Plan by the Koryo Democratic Confederation of 10 October 1980 (cited from KIM MYUNG-KI, The Unification Policies of the South and the North (The Institute for International Affairs, Seoul, 1995) 181-4.
} 
"In the process of negotiation for replacing the current Armistice Agreement with a progressive peace treaty, the North will not talk with the South but with the United States directly. Because the South did not sign the Armistice Agreement, it has no authority to be an opposite party for making a peace treaty." 95

Despite the fact that no representative of South Korea has officially signed the Armistice Agreement, North Korea's argument on this issue has little relevance in view of the existing opinio juris with respect to the following facts: ${ }^{96}$ firstly, General MARK CLARK did not sign only as a representative of the US army, but also as the UN Commander-in-Chief on behalf of all the military forces ${ }^{97}$ under the flag of the UN. ${ }^{98}$ The South Korean army was of course included in this chain of command. Secondly, South Korea participated in the post-Korean War Political Conference at Geneva in AprilMay 1954 as a party pursuant to Article IV, paragraph 60 of the Armistice Agreement. $^{99}$ The fact that neither of the two sides denied South Korea

95 North Korea firstly proposed North Korean-US direct contact on 25 March 1974. See "Letter to the United States Congress", Rodong Shinmun daily of 26 March 1974. In 1984, the North began to advocate a "Tripartite Meeting", but later reverted to its original policy on 28 April 1994. See The Korea Times of 28 April 1994. For details, see KIM HAKJOON, Unification Policies of South and North Korea 1945-1991: a comparative study (S.N.U. Press, Seoul, 1992) 412-8.

96 Regarding the legal characteristics of the Korean armistice agreement, see E.A.SIMON, "The operation of the Korean armistice agreement", 47 Military Review (1970) 105-39; S.POLLACK, The Korean Armistice: Collective security in suspense (Army Lawyer, Dept.of Army Pamphlet, 1984) 43-52; C.F.MURPHY, "Pueblo EC 121 and beyond: a suggested analysis", 38 Fordam Law Review (1970) 439-54. (cited from KIM CHIN, Korean Law Study Guide (San Diego, 1995) 38.

97 The Security Council, in its resolution of 7 July 1950, permitted the UN Member States to dispatch military forces for the maintenance of peace and security on the Korean peninsula and in that context to set up a united command under the UN flag. Therefore, an official signature of the UN Commander-in-Chief may be regarded as a legal act to represent at least the will of these forces and South Korea. See UNSC Res.84 (7 July 1950).

98 The treaty-making capacity of the United Nations as a legal person was examined by the International Court of Justice in its advisory opinion in the Reparation for Injuries case. In this Opinion, the Court has come to the conclusion that the United Nations has international personality and is able to conclude a treaty, by the following statement: "The Convention on the Privileges and Immunities of the United Nations of 1946 creates rights and duties between each of the signatories and the Organization. It is at present the supreme type of international organization, and it could not carry out the intentions of its founders if it was devoid of international personality. It must be acknowledged that its Members have clothed it with the competence required to enable those functions to be effectively discharged. " ICJ Yearbook 1948-9 at 66-70.

99 The article reads: "A political conference of a higher level of both sides be held by representatives appointed respectively to settle through negotiation the questions of the withdrawal of all foreign forces from Korea, the peaceful settlement of the Korean question, ...etc." Pursuant to that provision, the representatives of South Korea, the United States and the fifteen other nations that formed the unified forces met with delegates from the Soviet Union, China and North Korea in Geneva between April and June of 1954. It was clearly stated at that conference that the UNC would continue to be stationed in South Korea until the danger of a recurrence of war no longer existed. See 16 Foreign Relations of the United States [FRUS] 1952-54 (The Geneva Conference) (US Dept.of State, 
participation at that time shows that the latter was a legitimate party to the Armistice Agreement. ${ }^{100}$ Finally, South Korea has been the de facto main opposing party to North Korea in the political and military relations since the conclusion of the Armistice Agreement. ${ }^{101}$ All these precedents preclude North Korea under international law from denying South Korea the status of party in peace treaty negotiations.

\subsection{The United Nations Command (UNC) in South Korea and the Inter-Korean peace treaty-making process}

The third question with which we are confronted is that of the existence of the United Nations Command (UNC) ${ }^{102}$ in South Korea and whether it should be dissolved in the face of the issue of making an inter-Korean peace treaty.

The United States and South Korea hold that the UNC has been legally established and maintained in South Korea to ensure complete compliance with and observance of both letter and spirit of the Armistice Agreement, as stipulated in Paragraph 17 (Article II) of the Armistice Agreement. ${ }^{103}$ The establishment and existence of the UNC has, however, created a number of controversial legal problems. First, unlike two other organs, the Military Armistice Commission and the Neutral Nations Supervisory Commission, which can clearly be traced back to the Armistice Agreement, ${ }^{104}$ the UNC was not established by mutual accord, but unilaterally, by the United States and South Korea, for political and military reasons, on the basis of UN Security Council resolution 84 of 7 July 1950 . Its existence could, therefore, be seen as a violation of the spirit of the Armistice Agreement, which is to

\footnotetext{
Washington, D.C., 1981). See also Documents Relating to the Discussion of Korea and Indo-China at the Geneva Conference (April 16-June 15, 1954) (British White Paper No. 9186, London, 1954). 100 See LEE CHANG-HEE, "A method for replacing the Korean Armistice Agreement with a peace treaty system" (in Korean), 39 The Korean Journal of International Law (1994) No.1 at 65-6.

101 In July 1997 North Korea accepted four-party talks among North and South Korea, China and the United States. This symbolized a change in the North Korean position. "South and North Korea, and the United States agree 4-party talk in New York", Chosun Ilbo of 2 July 1992 at 2.

${ }^{102}$ The UNC was actually organized as a "unified command" by Security Council resolution 84 (S/1588), but after the armistice it has generally been called the "United Nations Command".

${ }^{103}$ Para. 17 reads: "Responsibility for compliance with and enforcement of the terms and provisions of this Armistice Agreement is that of the signatories hereto and their successors in command. The Commanders of the opposing sides shall establish within their respective commands all the measures and procedures necessary to ensure complete compliance with all of the provisions hereof by all elements of their commands. They shall actively cooperate with one another and with the Military Armistice Commission and the Neutral Nations Supervisory Commission in requiring observance of both the letter and the spirit of all of the provisions of this Armistice Agreement."

${ }^{104}$ Art. II, section B (Military Armistice Commission) and section C (Neutral Nations Supervisory Commission) of the Armistice Agreement.
} 
ensure a complete cessation of all acts of armed force in Korea. ${ }^{105}$ Second, the legal nature of the UNC is quite ambiguous. It was established during the war and is a unique entity in the history of the United Nations. It has definitely a kind of authority different to that of the UN armed forces in peace keeping operations. ${ }^{106}$ The opinio juris in South Korea, that the UNC is a subsidiary organ ${ }^{107}$ of the United Nations, ${ }^{108}$ has very little ground. During the war, neither the Security Council nor the General Assembly of the UN adopted any legal or policy instrument that endowed this unified command with the official status of a subsidiary organ of the United Nations. The UN merely authorized each military force under the unified command limited power to use the UN flag "in the course of operations against North Korean forces." 109 Besides, after the ceasefire in July 1953 the United Nations did not take any follow-up measures for the maintenance of the UNC. In the light of the wording of Security Council resolution $84^{110}$ and the following omission of the UN, the UN flag should in fact not have been used, as of the time that the actual military operations against North Korea's People's Army were terminated by the armistice.

The dissolution of the UNC in South Korea was first discussed as part of the official agenda of the $29^{\text {th }}$ session of the UN General Assembly in 1974. North Korea proposed the unconditional dissolution of the UNC and the withdrawal of foreign troops from South Korea. South Korea claimed that the UNC was essential for the implementation of the Armistice Agreement. Against this backdrop, the General Assembly adopted Resolution 3333 $(\mathrm{XXX}),{ }^{111}$ which was a compromise but stood closer to the South Korean

\footnotetext{
105 Preamble to the Armistice Agreement.

${ }^{106}$ On the definition of the UN peace keeping operation, see A.CASSESE (ed.), United Nations Peace Keeping: legal essays (Sijthoff \& Noordhoff, Alphen aan de Rijn, 1978) 15-6. On the background of the institution of peace keeping operations, see W.R.ERYE, A United Nations Peace Force (Oceana, New York, 1957). For documentation on peace keeping operations, see W.G.SHARP (ed.), A collection of primary documents and readings governing the conduct of multilateral peace operation (American Heritage, New York, 1995).

107 On the subsidiary organs of the UN, see Art.7 (2) of the UN Charter.

108 See e.g., LEE CHANG-HEE, loc.cit.n. 100 at 67; JHE SEONG-HO, "South Korea's strategy against the proposal of North Korea to conclude the peace treaty" (in Korean), 1 Seoul Journal of International Law (1994) 123.

109 S/1588 para.5 (7 July 1950). On this issue, see CHEE CHOUNG-IL, "Legal aspects of the United Nations Command in Korea", in CHEE CHOUNG-IL (Ed.), Korea and International Law (Seoul Press, Seoul, 1993) 84-96.

110 Ibid.

111 "The General Assembly expresses the hope that the Security Council will in due course give consideration to those aspects of the Korean question which fall within its responsibilities, including the dissolution of the United Nations Command in conjunction with appropriate arrangements to maintain the Armistice Agreement which is calculated to preserve peace and security in the Korean peninsula." Text of resolution in Yearbook of the United Nations 1974 at 173.
} 
position. ${ }^{112}$ Immediately after the adoption of the resolution, both sides began to prepare for another confrontation at the next General Assembly session. At the $30^{\text {th }}$ session in 1975 a pro-North Korean draft resolution proposed the dissolution of the UNC "immediately and unconditionally," and the withdrawal of all foreign troops there under the UN flag. The North Korean representative specifically emphasized that, if all foreign troops were withdrawn from South Korea concurrently with the dissolution of the UNC, no gap would in fact be created. ${ }^{113}$ On the other hand, a pro-Western draft resolution for the first time agreed on the need for such dissolution, but only after agreement was reached on intermediate measures, because without such arrangements, a military and legal vacuum could arise which might jeopardize the existing mutual understanding. The US representative also announced that the US would propose the holding of a conference not only to discuss means for the preservation of the Armistice Agreement but which could also explore other means to reduce tensions on the Korean peninsula. ${ }^{114}$ Remarkably, the General Assembly on 18 November 1975 passed two quite contradictory resolutions (3390 A \& B) on the question of the UNC in South Korea. ${ }^{115}$ Through Resolution 3390A, South Korea agreed to the dissolution of the UNC but only in conjunction with alternative arrangements for maintaining the Armistice Agreement; North Korea, through Resolution 3390B, asserted its wish to dissolve the UNC and to have all foreign troops stationed in South Korea under the flag of the United Nations withdrawn. ${ }^{116}$ Despite their contradictory contents, the two General Assembly resolutions coincided on the desirability of the dissolution of the UNC in South Korea. From this point on, the UNC was deprived of its legal basis ${ }^{117}$ and the UN was officially presumed to have abdicated its responsibility for restoring peace and security on the Korean peninsula.

\footnotetext{
112 See LyOU BYUNG-HWA, Peace and unification in Korea and international law (Occasional Papers in Contemporary Asian Studies 2, Maryland University School of Law, 1986) 82.

113 See KoH KWANG-LIM, loc.cit.n.24 at 547.

114 Ibid.

115 LYOU BYUNG-HWA, op.cit.n.112 at 83-6.

116 UN Chronicle 1975 No.12 at 18-21.

117 Prof. LeE CHANG-HEE, loc.cit.n.100 at 62, maintains that the UNC lost its legal basis since the two Koreas simultaneously became members of the UN in 1991. He contends that Security Council resolution 702 of 17 Sept.1991 legally replaced that of 7 July 1950 which branded North Korea as a peace-breaking country and served as the legal basis for the establishment of the UNC. This legal reasoning may be problematic, however. The United Nations did not explicitly branded North Korea as a peace-breaker, but determined, through Security Council resolution (S/1501), that the armed attack upon the Republic of Korea by forces from North Korea constituted a breach of the peace. Legally speaking, the breach of peace committed by the armed attack of North Korea had terminated by the cessation of hostilities and the conclusion of the Armistice Agreement on 27 July 1953.
} 


\subsection{The stationing of US armed forces in South Korea and the legal implications for Inter-Korean peace treaty-making efforts}

The final issue to be dealt with is that of the stationing of the US armed forces in South Korea. These forces were sent to the Korean peninsula in $1950^{118}$ in order to repel North Korea's armed attack on South Korea. ${ }^{119}$ In spite of the armistice of 1953, they were not withdrawn and have continued to be stationed in South Korea for strategic considerations, forming a critical issue in the postwar inter-Korean relations. On the one hand, North Korea has consistently demanded their withdrawal from South Korea, regarding their presence as a grave hindrance to peace and stability on the Korean peninsula; ${ }^{120}$ on the other, South Korea and the United States have rejected withdrawal, maintaining that the forces constitute an important stabilizer of the military balance on the Korean peninsula and in Northeast Asia as a whole. ${ }^{121}$

The stationing of the US armed forces is based on a ROK-US Mutual Defense Treaty ${ }^{122}$ and a Status of (US) Forces Agreement (SOFA). The Mutual Defense Treaty came about after arduous negotiations ${ }^{123}$ and was concluded on 1 October $1953,{ }^{124}$ just after the signing of the Armistice Agreement, in accordance with the South Korean government's wish to have a kind of defense treaty with the United States. It was meant to guarantee military stability and security on the Korean peninsula. ${ }^{125}$ Like other defense

118 The 7th Infantry Division of the US Army first landed in Korea on 8 Sept.1945 to receive the Japanese surrender on the Korean peninsula, but was evacuated in 1949. See KIM JUNG-IK, The future of the US-Republic of Korea military relationship (McMillan, New York, 1996) 31.

119 On the US military intervention in the Korean War, see S.AMBROSE, Rise to Globalism: American foreign policy since 1938 at 114-126. See also P.PIERPAOL, Truman and Korea: the political culture of the early cold war (University of Missouri Press, Columbia, 1999).

${ }_{120}$ See LYOU BYUNG-HWA, op.cit.n.112 at 107-10.

121 Id., at 99-105.

122 The international legal basis for the ROK-US Mutual Defense Treaty may be found in Art.52 para. 1 of the UN Charter. It provides that "Nothing in the present Charter precludes the existence of regional arrangements for the agencies for dealing with such matters relating to the maintenance of international peace and security as are appropriate for regional action."

${ }^{123}$ On the negotiation process of the Mutual Defense Treaty, see KIM HYUN-DONG, Korea and the United States: The evolving trans-Pacific alliance in the 1960s (Research Center for Peace and Unification of Korea, Seoul, 1990) 73-88.

124 It entered into force on 17 November 1954.

125 Another hidden reason for the RHEE SYNGMAN administration of South Korea to conclude a mutual defence treaty with the United States was to raise enough funds for the postwar restoration of the Korean economy based on the military stability on the Korean peninsula under the auspices of the US forces. In the negotiation process of the Mutual Defense Treaty, President RHEE urged the US to help the South Korean government modernize its army. With the so-called free ride security policy, the RHEE administration started the postwar restoration project. See KIM HONG-NAK, Perspectives on US-Korean Security Relations: Emerging patterns of regional security in Northeast Asia and the future of the US-ROK alliance (Council on US-Korean Security Studies, Proceedings 
treaties concluded after World War II, the ROK-US Mutual Defense Treaty, in its preamble and six articles, deals with suitable measures for the deterrence of external armed attack, ${ }^{126}$ for the settlement of international disputes, ${ }^{127}$ and some other administrative issues. ${ }^{128}$

The status of the US forces in Korea is, meanwhile, regulated by the SOFA. ${ }^{129}$ Its initial version was embodied in the Taejon Agreement of $1950 .{ }^{130}$ In it, South Korea granted the United States exclusive jurisdiction ${ }^{131}$ over American servicemen in Korea during the Korean War. Later a modified SOFA was drawn up under Article 4 of the Mutual Defense Treaty authorizing subsequent agreements regarding the disposition of American troops. ${ }^{132}$ The new SOFA ${ }^{133}$ superseded the earlier Taejon Agreement. ${ }^{134}$

In spite of all these arrangements, the stationing of US armed forces in South Korea has remained a critical issue from an international political perspective. Legally speaking, there is little room for North Korea as a third country to intervene in the stationing of US armed forces in South Korea, since the Mutual Defense Treaty is of a bilateral nature and concluded under the sovereign jurisdiction of the contracting parties. There is no significant postwar practice of a state's substantially intervening in the stationing of foreign forces in the territory of another (neighboring) country. North Korea

of the Fourth Annual Conference, 1988, Hawaii) 92-3.

${ }^{126}$ Art. 2 of the Mutual Defense Treaty.

127 Art.1 of the Mutual Defense Treaty.

128 Arts.3-6 of the Mutual Defense Treaty.

129 The official name of the Korean SOFA is Agreement regarding Facilities and areas and the Status of United States Armed Forces in the Republic of Korea. It was concluded under Art.IV of the ROK-US Mutual Defense Treaty. The SOFA is an executive agreement concluded on the basis of the executive power of the US President. On executive agreements, see L. HENKIN, Foreign Affairs and the US Constitution, (Oxford, 1996), pp. 215-26.

${ }^{130}$ Agreement of 12 July 1950. Text in United States Treaties and Other International Agreements [UST] 5:2, TIAS No.3012. For details, see D.W.BOWETT, United Nations Forces (Praeger, New York, 1964) 57.

131 Different from the Korean SOFA which grants exclusive criminal jurisdiction over American servicemen in Korea to the US, the NATO SOFA provided for dual or concurrent jurisdiction over American troops. Art.VII of the NATO SOFA. See Student comments, "Due process challenge to the Korean Status of Forces Agreement" (Student comments), 57 The Georgetown Law Journal (1969) 1097.

132 "The Republic of Korea grants, and the United States of America accepts, the right to dispose of United States land, air and sea forces in and about the territory of the Republic of Korea as determined by mutual agreement." Art. 4 of the Mutual Defense Treaty.

${ }^{133}$ A highly topical question of the SOFA is that of the criminal jurisdiction laid down in Art. XXII. It mirrors the system of original and concurrent jurisdiction incorporated in the earlier NATO SOFA. On the criminal procedure of American servicemen under Art. XXII of SOFA, see LEE J.Y., "Fair trial standards and Korean Criminal Law and procedures", 6 The Korean Journal of Comparative Law (1978) 15-42.

134 See "Due process etc.", loc.cit.n.131 at 1099. For the Korean perspective of the SOFA, see LeE Sog-U, A Study on the Korean Status of Forces Agreement (Soulsi Publishers, Seoul, 1995). 
might oppose the military activities of US forces in and around South Korea by invoking the right of self-defense under the UN Charter. ${ }^{135}$ If North Korea were to consider the military operation of US forces to be beyond a reasonable defensive scope and threatening its national security, ${ }^{136}$ it could require the United States to call off such an operation on grounds of constituting a menace to its peace and security and invoke its wrongful nature under international law, resulting in state responsibility. ${ }^{137}$ Despite these juridical possibilities, such a response would probably not be effective because a breach of an international obligation of a state has usually been interpreted restrictively in current international law. ${ }^{138}$ The Korean question is of a highly political content and the best way of resolving it seems to be by reaching an accord between the two sides directly involved.

\section{A REVIEW OF THE PROCEDURES TO BE FOLLOWED IN MAKING AN INTER-KOREAN PEACE TREATY}

\subsection{An inter-Korean peace treaty and the Vienna Convention of 1969}

The legal procedure to be followed for the making of an inter-Korean peace treaty may be generally found in the Vienna Convention on the Law of Treaties of 1969 (The Vienna Convention). ${ }^{139}$ Regarding the capacity

135 The scope of self-defense should be consistent with the purposes and principles of the United Nations. See Art.52, para.1 of UN Charter. On the theory of self-defense in international law, see L.F.DAMROSCH and D.J.SCHEFFER, Law and Force in the New International Order (Westview, Boulder, 1991).

136 One of the controversial military issues is found in the annual "Team-Spirit" joint military exercises.

${ }^{137}$ Pursuant to Art.3 of the International Law Commission's draft articles on State Responsibility, "An international wrongful act of a state may happen when (a) conduct consisting of an action or omission is attributable to the state under international law; and (b) that conduct constitutes a breach of an international obligation of the state."

${ }^{138}$ For details, see P.MALANCZUK, "Countermeasures and self-defense as circumstances precluding wrongfulness in the International Law Commission's draft articles on state responsibility", in M.SPINEDI \& B.SIMMA (eds.), United Nations Codification of State Responsibility (Oceana, New York, 1987) 246-51. See also J.CRAWFORD's Second Report to the ILC. This new version of the draft articles on state responsibility was adopted at the 51st session of the Commission at its 1999 session. See A/CN.4/498.

139 On the process of how the Vienna Convention of 1969 came about, see The Yearbook of the International Law Commission 1966 Vol.2 at 1, 51 and 169; United Nations Conference on the Law of Treaties, First Session, Official Records, A/CONF.39/11; Second Session, A/CONF.39/11 Add.1. See also, inter alia, I.M.SInCLAIR, The Vienna Convention on the Law of Treaties (Manchester, 1984); T.O.ELIAS, The Modern Law of Treaties (Oceana Publications, 1974); R.P.DHOKALIA, The Codification of Public International Law (Manchester, 1970); S.ROSENNE, The Law of Treaties: A guide to the legislative history of the Vienna Convention (A.W. Sijthoff, Leiden, 1969). Text of the Convention in, inter alia, 8 ILM (1969). 
of the parties concerned to the peace treaty making, first, Article 6 of the Vienna Convention endows all states with the power to make treaties. ${ }^{140}$ This means that only a state can be a subject of a treaty ${ }^{141}$ under current international law. ${ }^{142}$ Moreover, states that express their consent to being bound by a treaty will be the parties directly concerned. ${ }^{143}$ In the case of inter-Korean peace treaty making, accordingly, the two Koreas would be the parties directly concerned if they independently and clearly show their consent to being bound by the treaty.

Once committed to the making of a peace treaty, the governments of the two sides should talk about drafting the treaty text. The treaty text would include, by and large, such elements as preamble, national entity, political and territorial clauses, military détente, and economic and financial clauses. ${ }^{144}$ When the contents of the treaty are agreed upon, the draft of the peace treaty would have to obtain the final consent of, and be adopted by, the two sides. Upon the adoption of the treaty text, they would establish the text as authentic and definitive by such procedures as may be provided for in the text or as agreed to otherwise. ${ }^{145}$ However, the adoption and the authentication of the text would not in themselves create obligations for the two Koreas. The peace treaty would finally enter into force in such a manner and upon such a date as it may provide, or as soon as the consent to be bound by the treaty is expressed by the parties concerned. ${ }^{146}$ As is stipulated in

140 "Every State possesses capacity to conclude treaties." For details, see Sinclair, op.cit., at 29-30.

141 On the self-determination of state under international law, see J.CRAWFORD, The Creation of States in International Law (Oxford, 1979) 84-106. On the traditional theory of the state in international law, see J.B.SCOTT, Law, the State, and the International Community, 2 Vols. (Columbia Univ.Press, New York, 1939). See also H.KELSEN, General Theory of Law and State (transl. A.WEDBERG, Harvard, 1945); id., Pure Theory of Law (transl. from German original of 1934, Univ. of California Press, Berkeley, 1967) 279-319; B.AKZIN, "Analysis of state and law structure", in S.ENGEL (ed.), Law, State, and International Legal Order [Essays in honor of Hans Kelsen] (University of Tennessee Press, Knoxville, 1964) 2-17.

142 Under the orthodox positivist doctrine, states alone are recognized as legal persons in public international law. This absolute state sovereignty has become obsolete in the twentieth century, because of the increased need for international organizations to operate independently on the international level, separate from the member states, requiring a legal personality of its own both within the domestic legal order and under public international law. For example, the European Union has the right to make treaties on behalf of member states. See H.SCHERMERS \& N.BLOKKER, International Institutional Law (Martinus Nijhoff Publishers, The Hague, 1995) 976-7. On the legal personality of states and international organizations, see H.LAUTERPACHT, International Law: Collective papers, Vol.2 (Cambridge) 489; J.W.VERZIJL, International Law in Historical Perspective Vol.2 (A.W.Sijthoff, Leiden, 1970); M.N.SHAW, International Law (Cambridge, 1997) 139 et seq.

143 Art.12 para.1 of the 1969 Vienna Convention.

144 On the model of a peace treaty, see W.GREWE, "Peace treaties", EPIL inst.4 at 106-7.

145 Art.10 (a) of the 1969 Vienna Convention.

146 Art. 24, paras 1 and 2 of the 1969 Vienna Convention. 
Article 11 of the Vienna Convention, ${ }^{147}$ the most popular means of expressing consent are signature and ratification. ${ }^{148}$ In the case of an inter-Korean peace treaty, signature by the qualified treaty-making organ ${ }^{149}$ and ratification by the parliaments of the two Koreas would be the most appropriate method. When the peace treaty enters into force, it should be transmitted to the UN Secretariat for registration ${ }^{150}$ in accordance with Article 102 paragraph 1 of the UN Charter. ${ }^{151}$

\subsection{The replacement of the armistice agreement with a peace treaty}

In the case of an inter-Korean peace treaty, an additional problem is the replacement of the Armistice Agreement with the peace treaty. This procedure, which consists of terminating the previous treaty and the entering into force of the new treaty, ${ }^{152}$ raises some legal problems under the Vienna Convention on the Law of Treaties of 1969.

The first step in the replacement of the Armistice Agreement would be to terminate the Armistice Agreement itself. Termination of a treaty means the ending both of the treaty itself and of the rights and obligations it has created. ${ }^{153}$ With regard to this question the Vienna Convention contains relevant rules in its Part IV (Articles 54-64). Under Article 54, a treaty may be terminated (a) "in conformity with the provisions of the treaty" or (b) "at any time by consent of all the parties after consultation with the other contracting States." 154 The Korean Armistice Agreement does not include rules on its termination and thus the only way to terminate the Agreement under the Vienna Convention system is for the parties directly concerned to agree on its termination. ${ }^{155}$ On the same subject, however, the Vienna Convention

147 "The consent of a State to be bound by a treaty may be expressed by signature, exchange of instruments constituting a treaty, ratification, acceptance, approval or accession, or by any other means if so agreed."

148 For details, see MALANCZUK, op.cit.n.6 at 131-2.

149 Art.7, paras 1 and 2 of the 1969 Vienna Convention. The qualified treaty-making organs should produce appropriate full powers to represent the state, or the intention of the state to consider that organ as representing that state should appear from the latter's state practice.

150 Art.80 para.1 of the 1969 Vienna Convention.

151 "Every treaty and every international agreement entered into by any Member of the United Nations after the present Charter comes into force shall as soon as possible be registered with the Secretariat and published by it."

152 For details, see A.E.DAVID, The Strategy of Treaty Termination (Yale, 1975) 56-8.

153 See N.KONTOU, The Termination and Revision of Treaties in the Light of New Customary International Law (Oxford, 1994) 8.

154 For details, see MALANCZUK, op.cit.n.6 at 141.

155 Art.54 of the Vienna Convention. Outbreak of general armed hostilities in Korea would be another reason for terminating the Armistice Agreement under the current system of the law of treaties (Art.73 of the Vienna Convention). It is, however, not sensible to include outbreak of war 
contains yet another provision, Article 56, paragraph $1(\mathrm{a})$ and (b), ${ }^{156}$ which recognizes a right of unilateral denunciation or withdrawal subject to certain conditions. If a treaty is silent on its termination and does not provide for denunciation or withdrawal, a right of denunciation or withdrawal is acknowledged if (a) it is established that the parties intended to admit the possibility of denunciation or withdrawal"; or (b) "a right of denunciation or withdrawal may be implied by the nature of the treaty." 157 In light of the modern trend towards general armistices, ${ }^{158}$ North and South Korea may supposedly be entitled to invoke the article because the Armistice Agreement signifies, by its nature, that de facto termination of the Korean War by the armistice is to be consummated by a final peace treaty.

From a rather academic point of view one could envision a fundamental change of circumstances (rebus sic stantibus) as a ground for the termination of the Armistice Agreement. ${ }^{159}$ Pursuant to Article 62 paragraph 1(a) and (b) of the Vienna Convention, rebus sic stantibus may be invoked as a ground for treaty termination or withdrawal if (a) the changed circumstance itself constitutes "an essential basis of the consent of the parties to be bound by the treaty" and (b) the effect of the change is "radically to transform the extent of obligations still to be performed under the treaty". ${ }^{160}$ The relevant question is, then, whether the essential basis of the Korean armistice system has indeed changed. Admittedly, external circumstances have changed considerably, especially since the two Koreas simultaneously joined the UN in 1991. However, a strict interpretation of the wording of Article 62, paragraph 1 of the Vienna Convention does not really show any radical transformation

in the present context, as the termination of the Armistice Agreement by the outbreak of war would imply the collapse of the de facto peace. For details, see MALANCZUK, op.cit.n.6 at 145.

156 Art.56 para.1(b), which was added to the text of the Vienna Convention of 1969, mainly reflects the view of most British writers, contrary to that of many continental authors, according to whom there could never be an implied right of denunciation or withdrawal under customary international law. See MALANCZUK, op.cit.n.6 at 142. On the British opinion, see A.D.MCNAIR, The Law of Treaties: British practice and opinions (Columbia, New York, 1938) 362-4. On this question, the position of the ICJ has become clear since it decided in Nicaragua vs. USA that Art.56 was an accurate statement of customary law. See ICJ Reports 1984, 392.

157 Art.56 of the 1969 Vienna Convention. For details, see I.SINCLAIR, op.cit.n.139 at 186-8.

158 See STONE, op.cit.n.33 at 644.

159 On the doctrine of Rebus Sic Stantibus in international law, see A.VAMvouKos, Termination of Treaties in International Law (Oxford, 1985) 60-151.

${ }^{160}$ In the Fisheries Jurisdiction case, the ICJ held: "International law admits a fundamental change in circumstance which determined the parties to accept a treaty, if it has resulted in a radical transformation of the extent of the obligations imposed by it. This principle has been embodied in Article 62 of the Vienna Convention on the Law of Treaties, which may in many respects be considered as a codification of existing customary law on the subject of the termination of a treaty relationship." ICJ Reports 1973 para.36. 
of inter-Korean relations. ${ }^{161}$ Consequently, there is hardly reason for rebus sic stantibus to be applied to the current Korean situation.

Once the Armistice Agreement is officially terminated in accordance with the Vienna Convention, there will be an option to take one of two different paths: first, the new peace treaty simultaneously enters into force, replacing the Armistice Agreement or second, an interim stage be introduced before the final effectuation of the peace treaty. The first alternative would not raise any problems. In the case of the second alternative, however, the two Koreas would have to define clearly the legal nature of that interim stage.

\section{EVALUATION AND CONCLUSION}

In this article, we have examined the legal problems related to the establishment of a de jure peace regime on the Korean peninsula, focusing on the making of a formal inter-Korean peace treaty under international law.

In order to construct a stable peace regime on the Korean peninsula, the two Koreas have to meet certain critical legal conditions. The initial step is to clarify the current legal status of the inter-Korean relationship. With the many changes over the last decades, the two Koreas are neither at peace nor in a state of armistice in the traditional sense. Having analyzed the substantive characteristics of the Korean armistice under the modern international law of war, we have come to the conclusion that the current legal state of interKorean relations should be regarded as an interim stage between de jure armistice and de facto peace. Starting from this assumption, further conditions have been discussed. In regard to qualification as the parties directly concerned the present inquiry has clearly shown that North and South Korea are without any shadow of a doubt to be classified as such.

The next question concerns the existence of the UNC in South Korea. Whether it should be dissolved before the peace treaty-making process begins has been a long-standing issuebetween the two sides. The UNC has been deprived of its legal basis not only by the General Assembly Resolutions 3390 (A \& B), but also by the simultaneous entry of the two Koreas into the UN in 1991. Its official dissolution would certainly create a better climate towards establishing a peace regime on the Korean peninsula.

In addition to these two conditions, the stationing of the US armed forces in South Korea has been examined. We have found that this is a political rather than a legal issue. Legally speaking, there is little ground for North Korea to raise objections against the stationing itself, except when an actual military operation is considered to be gravely threatening to its national security and to constitute a breach of an international obligation. Since a breach of an international obligation by a state is very strictly defined in

${ }^{161}$ For state practice on fundamental change of circumstances with respect to treaties, see VAMvOUKOS, op.cit.n.159 ibid. 
current international law, the best way of resolving this question seems to be to reach an accord directly between the parties concerned.

On the basis of a review of the legal conditions, we have touched upon the procedure of inter-Korean peace treaty making under the Vienna Convention on the Law of Treaties of 1969. Under the Vienna Convention, an interKorean peace treaty could be brought about through the following procedure. First, North and South Korea should agree on who will be the parties to the peace treaty. Our inquiry has shown that the two Koreas are qualified to act as the parties directly concerned. Next, they should express their consent to be bound by a peace treaty after which they would draft and adopt a treaty text including the crucial issues of establishing a genuine peace regime on the Korean peninsula. The process would be completed by the ratification of the treaty.

The finalization of the peace treaty, however, requires North and South Korea to complete another vital procedure: the replacement of the Armistice Agreement with the peace treaty. Because the Armistice Agreement does not meet the requirements for treaty termination as laid down in Article 54 of the Vienna Convention, the best way to terminate the Armistice Agreement seems for the two Koreas explicitly to agree on this step and for their respective agreements to be binding. The final step would then be the entry into force of the new peace treaty. 